\title{
Olvasóvá nevelés óvodáskorban a drámapedagógia módszereivel
}

\section{A mese komplex személyiségfejlesztő hatása ${ }^{1}$}

\author{
Gönczöl Andrea \\ ELTE TÓK Magyar Nyelvi és Irodalmi Tanszék
}

\begin{abstract}
Absztrakt
A tanulmány fókuszában az óvodáskorú gyermekek olvasóvá nevelésének, irodalom iránti kíváncsiságuk felébresztésének kérdései állnak. A szerző célja bemutatni a drámapedagógia azon módszereit, melyek elméleti és gyakorlati segítséget nyújthatnak az óvodapedagógusoknak a gyermekek beszéd- és viselkedéskultúrájának, érzelmi intelligenciájának fejlesztéséhez, az alapvető etikai kategóriák, fogalmak - mint például az elfogadás, nyitottság, tolerancia - gyakorlatban történő, játékos alkalmazásához. A drámapedagógiai módszerek és a mesereprodukciós formák tudatos és szakszerủ alkalmazása ösztönzi a gyermekeket a történetezés és narratívateremtés örömének felfedezésében, segítve szövegértésük és logikus gondolkodásuk fejlődését. Az írásban kiemelt szerepet kapnak az interaktív tevékenységi módok, a komplex személyiségfejlesztő drámajátékok, valamint a projektpedagógia elveire épülő drámatervek bemutatása.
\end{abstract}

Kulcsszavak: szövegértés, olvasóvá nevelés, mesereprodukció, történetalkotás, drámapedagógia

\section{Bevezetés}

Jelen tanulmány fókuszában az óvodáskorú gyermekek olvasóvá nevelésének, irodalom iránti kíváncsiságuk felébresztésének kérdései állnak.

A szerző célja bemutatni a drámapedagógia azon módszereit, melyek elméleti és gyakorlati segítséget nyújthatnak az óvodapedagógusoknak a gyermekek beszéd- és viselkedéskultúrájának, érzelmi intelligenciájának fejlesztéséhez, az alapvető etikai kategóriák, fogalmak - például elfogadás, nyitottság, tolerancia - gyakorlatban történő játékos alkalmazásához. A ta-

${ }^{1}$ A tanulmány Educational reading in preschool with methods of drama pedagogy. Complex personality development effect of tale címü angol nyelvü változatát lásd Gönczöl, 2019. 
nulmány az olvasás és írás óvodai előkészítésének, megalapozásának - kiemelten a beszédészlelés és beszédmegértés, szövegértés, szókincsfejlesztés - gyakorlataira is kitér röviden, valamint érinti az olvasás- és írászavarok prevenciójának kérdéseit, a zene és a nyelv feldolgozási folyamatainak, kapcsolatainak rendszerét, a zene transzferhatásainak, valamint a komplex müvészeti nevelés szerepének hangsúlyozását az olvasás és írás előkészítésében. A szerző az olvasóvá nevelés óvodai lehetőségeit is áttekinti, valamint azt, hogy az alapkultúrtechnikákhoz (kiemelten az olvasáshoz és az íráshoz) szükséges készségek és képességek fejlesztéséhez milyen módszerekkel tudunk - a gyerekek életkori sajátosságait szem előtt tartva - hozzájárulni.

\section{Beszédhallás}

A beszéd és írás elsajátításához nélkülözhetetlen, hogy a beszédfeldolgozás fö területei: a beszédészlelés, a beszédmegértés, az emlékezeti működés és a vezérlés folyamatai megfelelően működjenek, mely működés alapja az ép hallás, beszédhallás. Mint ismeretes , a 20-30 dB közötti hallásküszöbnél orvosi szempontból nem jelentős, enyhe eltérés, halláskárosodás jelentkezhet, azonban ez az érték az anyanyelv-elsajátítás során zavart okozhat a beszédpercepcióban (Gósy, 2000).

A beszédészlelés során a jelentés nélküli egységeket, a beszédhangokat és kapcsolódásaikat ismerjük fel és azonosítjuk. A beszédmegértés valójában szavak, szókapcsolatok, mondatok, illetőleg mondatok összességének, azaz egymásutániságának helyes felismerése, értelmezése és feldolgozása.

A beszédhanghallás két összetevője: a beszédhang felismerés (fonológiai észlelés) és a beszédhang kiemelés (fonológiai tudatosság) (Gósy, 2000).

A fonológiai tudatosság a szótagolást, a szó eleji és szóvégi hangok felismerését és hangoztatását, a beszédhanghallást, és a beszédhangot jelölő betű egyeztetését jelenti. Erre jó óvodai gyakorlatok lehetnek az auditív zártságot, fonológiai kódolást, transzformációs észlelést fejlesztő anyanyelvi játékok. Ide tartozik a hang lokalizációja, auditív zártság, szeriális észlelés fejlesztése, például: Hol hallod a kígyó hangot az asztal szóban? -, valamint transzformációs észlelés fejlesztése, vizuális minta auditív jellel történő összekapcsolása, például: bimbós és kinyílt tulipánok vizuális mintájának letapsolása.

A beszédészleléshez kapcsolódó részfolyamatok - szeriális észlelés, beszédhang-differenciálás, transzformációs észlelés, vizuális észlelés, ritmusészlelés, szupraszegmentumok észlelése - megfelelő működése kell a további területek, a beszédmegértés, a memória fejlődéséhez. A beszédészlelés funkciója az artikulációs mozgások elsajátításában, hangsorok, szavak felismerésében, az új szavak tanulásában, az olvasástechnika elsajátításában és az írás, helyesírás, idegen nyelv tanulásában rejlik (Gósy, 2000).

Bár ezek a részfolyamatok az anyanyelv-elsajátítás során alakulnak ki, az óvodáskor végére, az iskolába lépéshez bizonyos fokú fejlettségük szükséges. Nagy felelősség hárul tehát az óvodapedagógusokra, mert az intézményes „alapozó kurzus” óvodáskorban kezdődik. 


\section{A zene transzferhatásai}

A zene és a beszéd észlelése a hallás szempontjából a két legmagasabb fokú észlelési folyamat. Az éneklés és beszéd során is ugyanazt a vokális apparátust használjuk. A csecsemő gőgicsélése is zenei karaktereket tartalmaz, valamint a felnőttek csecsemőkkel folytatott kommunikációjában is az eltérő, megkülönböztetett dallamkészlet a jellemző (Réger, 2002).

Az olvasáshoz szükséges hallási képesség nem speciálisan fonématermészetü, zenei hallásképességgel is társul.

A beszéd és a zenei tartalom ugyanazon akusztikai tulajdonságok mentén szerveződik, melyek a hangmagasság, az időtartam, az intenzitás és a hangszín. Amíg azonban a zenében a hangmagasság változásainak észlelése a hangsúlyos, addig a beszédben a gyors időbeni változások észlelésére van szükség (Janurik, 2008).

Agyi képalkotó vizsgálatok alapján a zene és a nyelv feldolgozási folyamatainak közös idegi alapját feltételezik, például a hangmagasság-észlelés fejlettségének a nyelvi hangmagasság-információk dekódolására kifejtett pozitív hatását kutatásokkal igazolták (Janurik, 2008).

Ahogy a zenei hallás és zenei közlés is megfeleltethető a kommunikációs modell adó-vevő relációjának, úgy a zenei írás és olvasás is összefüggésbe hozható a nyelvi szövegek írásával, olvasásával.

A nyelv tudatformáló erővel rendelkezik, egy Japánban folytatott vizsgálatról Hámori József számol be (Bódis, 2005), és meggyőzően mutatja be a nyelv meghatározó szerepét. A japán nyelv gazdagabb a zenei elemekben, ezért a muzikális kérgi központ a jobb helyett szintén a bal féltekében alakult ki, a beszédközponthoz kapcsolódva. Ez nem így történt azoknál a japán gyermekeknél, akik angol nyelvi környezetben, Amerikában nőttek fel, vagyis nem genetikus örökségről van szó. A fentiek is alátámasztják, hogy a nyelv egészen a fizikális szintig meghatározhatja a nyelvbe beleszülető egyént, kiemelkedő szerepe lehet tehát a koragyermekkori nyelvi élményeknek, a szülői és óvodapedagógusi modellnek.

Számos kutatás kötődik a zene transzferhatásainak - többek között a nyelvi funkciókra, a szövegértésre gyakorolt hatásainak - vizsgálatához. Kutatások bizonyítják, hogy a gyerekkorukban zenei képzésben részesült felnőttek pontosabban tudják azonosítani az elhangzott mondatok érzelmi üzeneteit (Thompson, Schellenberg \& Husain, 2004). Janurik Márta (2008) szerint a korai olvasás fejlettségében meghatározó szerepet játszó fonológiai tudatosság és beszédhanghallás speciális zenei képzéssel fejleszthető.

Az írott szöveg olvasásakor nyelvi jeleket, kottaolvasáskor hangjegyeket fejt meg, dekódol a gyermek, mindkét müvelethez fontos a vizuális és az akusztikus észlelés, a térbeli helyzetek, a betük és a hangjegyek elhelyezkedésének észlelése. Janurik Márta (2008) kifejti, hogy a zenei hangok jelei, a hangjegyek elhelyezkedése horizontális és vertikális irányban is jelentéstartalommal bír, s ily módon a kottakép dekódolása a szövegolvasásnál komplexebb, térbeli észlelési és feldolgozási képességet kíván. 
A betűkép dekódolása esetén sem elhanyagolható szempont a betűk térbeli - akár horizontális, akár vertikális irányban történő - elhelyezkedésének észlelése, gondoljunk csak a diszlexiásokkal végzett látótér- vagy szemmozgás-vizsgálatokra, ugyanis a látótér akár függőleges, akár vízszintes irányú beszűkülése nehézséget okoz a betűolvasásban is (Donauer, 2016).

Más szerzők is megerősítik (Buzás \& Maródi, 2018), hogy az olvasás elsajátításához nélkülözhetetlen a téri viszonyok közötti pontos tájékozódás képessége. A kottaolvasás többdimenziós téri tájékozódást is igényel, mivel a hagyományos kottarendszerben a különböző magasságú hangok öt vonalban, négy vonalközben és további segédvonalakban jelennek meg (Fazekasné, 2006).

A zene és az olvasás egymásra gyakorolt hatását és kapcsolatát támasztja alá az is, hogy a nyelvi feldolgozás során megjelenő deficitek a zenei feldolgozás során is jelentkeznek A hangszerrel való ismerkedést is ajánlatos minél korábban elkezdeni, mivel a hangszeres játék a szenzoriális és motoros készségek, képességek összehangolását igényli, mely által az agyféltekék közötti összeköttetés megerősíthető (Janurik, 2008).

\section{Mesemondás és szövegteremtés}

A beszédhanghallás minősége befolyásolja a beszédhangok képzését, a beszédészlelés és beszédmegértés folyamatát, a szövegértő olvasást és a helyesírást.

Napjaink kommunikációját és a gyermekkor kultúráját meghatározza a kulturális jelölők anyaga: , a kép kiemelt szerepet kapott a gyermekirodalomban, a gyermekek számára is hozzáférhető technikai médiumokban (Daróczi, 2014). Az óvodáskori irodalmi élményt az óvodapedagógus beszéde strukturálja, az óvodások számára - olvasástudás hiányában - a pedagógus akusztikus mintázatának van óriási szerepe és felelőssége.

A képi kifejezések jelrendszere is információt közvetít, a képek jelentésteli felületek, éppúgy „elolvashatunk” egy riportfotót, rendőrségi rajzot, piktogramot vagy térképet is. „Elolvassuk” a hangulatjeleket (emotikonokat), sőt ezek már beépülnek/tek a gyermekek kommunikációjának eszköztárába. Ezt a tudást és ismeretet is felhasználhatjuk az óvodai irodalmi és drámatevékenységek során: az interaktív/szakaszos mesefeldolgozás módszeréhez (Szinger, 2009) jó játékötlet lehet, hogy a mese egyes szakaszainál színes hangulatkártyákkal, hangulatjelekkel fejezik ki a gyermekek az érzelmeket (például Hogyan érezheti most magát a mesehös? Hogyan érzed magad most a mesében?)

A megértés minősége függ gondolkodásunk rugalmasságától, mentális „képtárunk” gazdagságától, a társadalmi konvenciók vagy szakmai jelrendszerek ismeretétől. A gyermek a hallottakhoz belső képet készít, elaborál. Ez a tevékenység szorongás- és feszültségoldó, énerősítő hatású. Ez az igazi olvasóvá nevelés kezdete, soha nem válik igazi olvasóvá az, aki nem tud bel- 
ső képet készíteni az olvasott szöveghez (G. Gődény, 2014). Igazi beszélővé sem, hiszen gondolkodása képi elemekből tevődik össze.

Már az anyaméhben elkezdődik az olvasóvá vagy a nem olvasóvá nevelés: a prenatális akusztikus ingerek hiánya, az anya mozgással kapcsolatos attitűdje, az érzelmek, élmények, felnőtt-felnőtt beszéd-interakció megléte vagy hiánya mind-mind kihatnak a későbbi literációs szokásokra, az olvasásban való motiváltságra.

A technomédiumok alkalmazásának elterjedése óvodáskorban több kérdést, problémát is felvet, a gyerek nem használja a belső képteremtő képességét, kész információkat, képeket kap, így a mesehallgatás és a későbbi olvasás során nem tudja elaborálni a hallott, olvasott szövegeket, nem tud mentális képet alkotni a történethez. Csak az hallgat vagy olvas szívesen mesét, aki képes élvezni, amit hall, olvas, ehhez pedig szükség van az elaboráció képességére.

A gyermek szövegértését jól segíti a mesereprodukciós formák, az interaktív mesemondási technikák óvodai alkalmazása. Dankó Ervinné (2000) a mesereprodukció formái közé sorolja - többek között - a drámajátékot, a dramatizálást, a bábjátékot és a gyermeki elbeszélést. A gyermeki történetmondás egyedi - szinguláris - esemény: sem a beszélő hangoltsága, hangulata, sem a beszéd körülményei nem ismétlődnek meg ugyanabban a kontextusban, ugyanabban a narratív struktúrában még egyszer. A gyerek történetmondás közben különböző szövegalkotási műveleteket alkalmaz: analizál, szintetizál, sürít, helyettesít. A sok mesét, történetet élvezettel, empátiával hallgató és értő gyermek narratívateremtése során a mesei forma modelljét követi: szintaktikai invariánsokat, retorikai formákat, különböző nyelvi változókat használ fel meséléskor.

Rendkívül jól lehet alkalmazni a gyermeki történetmondásra, narratívateremtésre a Csimota Kiadó csak képeket tartalmazó meseköteteit, a Designsorozat darabjait (vö. Révész, 2019.). A „picture books” kicsi gyerekeknek (is) készített könyvekből áll, melyekben a képek adják a történetet. Ugyanúgy kell a képeket „olvasni”, mint a szöveget: megfigyelni a részleteket, az egymásutániságot, a történetet, az ok-okozati viszonyokat, sőt a rejtett tartalmakat is.

„A képekre ugyanúgy »válaszolhat « az »olvasó«, mint egy szövegre, kiegészítheti, folytathatja. A kép ezekben a könyvekben nem illusztráció, hanem a lényeg. Ezek a könyvek kiválóan alkalmasak az érdeklődés felkeltésére." (Adamikné, 2001) A sorozat különlegessége, hogy egy mesét több kortárs illusztrátor is feldolgozott egyéni technikákkal, stílussal, képi világgal.

Az ELTE TÓK kiemelkedő szakdolgozója, Varga-Mukri Erika (2019) óvodáskorú gyermekek szövegalkotási képességeit vizsgálta 20 fö 5-7 év közötti gyermek bevonásával. Kutatásához a Csimota Kiadó Design-sorozatából választott ki öt - a gyerekek által ismert - mesét. A sorozat különlegessége, hogy egy mesét több illusztrátor dolgoz fel szöveg nélkül. A gyerekek a sajátos képi ábrázolás (például a képregényekre emlékeztető storyboard technikával, keresztszemes hímzéssel, lego pixel figurákkal készült képek) alapján 
nem ismerték fel az egyébként jól ismert történeteket, mesealkotásuk során a képekre fókuszálva kellett megmozgatni képzeletüket, fantáziájukat és saját meseélményeikre támaszkodva dekódolni a mesék emblematikus nyelvét, előhívni mentális lexikonjukból a meseteremtéshez szükséges kifejezéseket. A tanulmány keretei nem teszik lehetővé a kutatás részletes bemutatását, azonban a - nem reprezentatív, de mégis figyelemre méltó - eredmények is azt támasztják alá, hogy a gyermekkori nyelvi élmények, az otthoni és óvodai rendszeres mesélés pozitívan hat a gyermekek nyelvi fejlődésére, szövegértésére, szókincsére. A gyermekek történetalkotásaiban megjelentek meseélményeik szintaktikai, stilisztikai variánsai, a mesei retorikai formák, bevezető és záró formulák, visszatérő mesei sztereotípiák, sőt a nyelvi humor, a helyzet- és jellemkomikum elemei is. A kutatás eredményei rávilágítottak arra is, hogy a gyerekek fogékonyak az absztrakt ábrázolásmódra, történetalkotásukkal a mesemondást is aktuálissá, spontánná teszik, s a képek alapján történő meseszövés alkalmat ad a többféle látásmód közvetítésére. A „picture books" típusú könyvek otthoni mesemondásra, szülö-gyermek interaktív játékára is kiválóak, hiszen a képekből mindenki megszőheti a saját kitalált történetét. A szülőknek nem kell idegenkedniük a szöveg nélküli mesekönyvektől: a gyerek kezébe adva hamar megszületnek az első „mesefilm-kockák”, amelyeket szülőként bekapcsolódva közös meseélménnyé tehetünk, és a végén még címet is adhatunk saját meséinknek.

\section{Irodalmi játékok, interaktív tevékenységi formák}

A hős mítosza mindegyik kultúrában megtalálható, s a hősmítoszok között nagyfokú strukturális hasonlóság figyelhető meg. A hősök tipológiájával sok mesekutató foglalkozott (csak néhányukat említve,. Nagy Olga, Jankovics Marcell, V. J. Propp, Boldizsár Ildikó), tanulmányunk következő részében a mesehősök tulajdonságaival, életútjával kapcsolatos néhány irodalmi játékot mutatunk be, melyek olyan interaktív tevékenységi formák, amelyek alkalmasak a gyermekek szövegértésének felmérésére és fejlesztésére.

Ismert mesékkel a következő mesejátékokat játszhatjuk:

\section{Szoborjáték}

Melyik mesehősnek állítanátok szobrot? Miért? Például a Benedek Elek által gyüjtött $A$ csúnya királyfi és a szép királykisasszony címü mesében szobrot állíthatunk a beképzelt, öntelt és hiú, de gazdag és szép királylánynak vagy a talpraesett, eszes és furfangos, de csúnyácska királyfinak (Benedek, 1989).

\section{Életúttérkép}

Nagyobbakkal megrajzolhatjuk a kiválasztott mesehős útját egy táblára rögzített vagy földre fektetett csomagolópapíron, megbeszélhetjük a hős feladatait, konfliktusait, azokat a tulajdonságait, melyek szükségesek lehettek az 
adott életfeladat teljesítéséhez, néhány külső-belső tulajdonságot szoborjátékkal is megformálhatunk.

\section{Körmese}

Az emberi tulajdonságok témaköréhez - akár projektjéhez - jól illeszkedik a következő körmese. Megteremtünk két gyermeket, az egyik gyermeknek a külső, míg a másiknak a belső tulajdonságait nevezzük meg körmesei formában, majd nevet adunk nekik, lerajzoljuk őket, kitalálhatunk történeteket is velük kapcsolatban, akár keresztezhetik is egymás útját (például ugyanabba az óvodai csoportba kerülnek, elmesélhetjük az első, óvodában töltött napjukat).

A fenti témához (projekthez) kapcsolódóan feldolgozhatjuk nagyobbakkal Lázár Ervin A csodapatika című meséjét. Rimapéntheki Rimai Péntekh patikájában rossz tulajdonságainkra lehet gyógyírt kapni, azonban hatása csak akkor lesz, ha mindenki felismeri saját gyengeségeit és maga kéri a gyógyszert a patikustól. A mese drámapedagógiai feldolgozásához jól felhasználhatók az önismereti játékok.

\section{Mesefolytatás, mesebefejezés}

Erre a játékra leginkább a befejezetlen vagy az úgynevezett „happy end nélküli mesék" a legalkalmasabbak, de bármelyik ismert mesét befejezhetjük másképp vagy folytathatjuk is a mese történetét. (például Mi történt a lakodalom után Csipkerózsikával és a herceggel, hogyan éltek tovább?) A mesebefejezés nemcsak verbális módon történhet, hanem drámapedagógiai munkaformákkal is: a mese befejező motívumait eljátszhatjuk állóképekkel vagy némajátékkal.

\section{Meseátstrukturálás}

Az életúttérkép játék során beszélhetünk a hős életútjának elágazásairól, arról, hogyan folytathatta volna másképp az útját, mi lett volna, ha egy másik ösvényt választ.

\section{Mesemondás másképp}

Meséljük el a történetet a boszorkány, a sárkány, a segítőtárs vagy a varázstárgy szemszögéből!

\section{Mimetizálás}

Nagyobb gyermekekkel eljátszhatjuk némajátékkal egy szólás vagy közmondás szó szerinti és átvitt értelmű jelentését, a többieknek pedig ki kell találniuk, hogy melyik volt az eljátszott közmondás vagy szólás (például Itatja az egereket, Addig jár a korsó a kútra, míg el nem törik, Ki korán kel, aranyat lel). 


\section{Talált tárgyak meséje}

A gyermekek a mesékből, hallott történetekből vett szüzsékre támaszkodva és saját élménytöredékeikből, fantáziájukból merítve alkothatják meg a talált tárgyak elö- és utótörténetét, $\mathrm{s}$ a jól irányított kérdésfeltevéssel egy komplex drámaórát rögtönözhetünk. Beszélgetésindító ötletek: „Ezt az esernyőt, mesekönyvet, játékmackót stb. az óvoda, iskola, házam stb. előtt találtam, elhoztam magammal. Mi lehetett a legboldogabb pillanata? Mi lehetett a legszomorúbb pillanata? Hogyan kerülhetett ilyen állapotba? Hogyan lehetne megint boldoggá tenni? Hogyan segíthetnénk?” A különböző tárgyak köré alkotott történet mindig magában hordoz integrációs lehetőségeket is, így akár a vizuális, akár a zenei, akár a természet megismerésére nevelés, vagy a testi nevelés területei is bekapcsolhatók a drámajátékokba.

\section{Tárgyjáték}

A tárgyjátékot jól ismert mesékkel játsszuk, fontos, hogy a tárgyak természete igazodjon a kiválasztott mese típusához, tartalmi elemeihez. (Például A kismalac és a farkasok - fürdőszobai eszközökkel, $A$ só - konyhai eszközökkel, $A$ csillagszemü juhász - sminkeszközökkel vagy világítótestekkel, Piroska és a farkas - zöldségekkel.)

\section{Kendőjáték}

Az ismert meséket színes kendőkkel játsszuk el, a gyermekek választják ki, melyik kendő jelzi az egyes meseszereplőket, helyszíneket. A gyermekek által kiválasztott kendőket „beléptetjük” a mesébe, ahhoz hasonlóan, mikor a drámajátékba belépünk és egy szerepet magunkra vállalunk. A tárgyjátékok és kendőjátékok tulajdonképpen a bábjátékhoz tartoznak, ezek a játékok is a gyermekek belső képteremto képességét, fantáziáját „mozgatják meg”. A gyermek ebben a játékban azt a meseszereplőt, helyszínt, varázstárgyat, amelyről korábbi meseélményei, tapasztalásai alapján mentális képe alakult ki, most behelyettesíti; itt a valóság tárgyaival való közvetlen kapcsolat és a szemléltetés összefüggése más, magasabb kognitív dimenzióban jelenik meg.

A szimbolikus gondolkodás jellemzője, hogy a gyermek képes reprezentálni mentálisan nem jelen levő képeket vagy eseményeket a szimbólumok segítségével. A szimbolikus képreprezentáció lehetősége a következő, szimultán módon előforduló magatartás megjelenésében lelhető fel: késleltetett utánzás (amelyik a modell hiányában történik), szimbolikus játék, rajz, mentális képalkotás (mintegy belső utánzás jelenik meg) és nagymértékben a nyelv, ami lehetővé teszi egy jelenség verbális felelevenítését.

A tárgyjátékokhoz és a fantázia, belső képteremtés fejlesztéséhez jól kapcsolódhat egyik kortárs szerzőnk, Finy Petra A csodálatos szemüveg (2011) című meséje, melyhez néhány játékötletet adunk. 
A gyerekek elkészíthetik saját csodálatos szemüvegüket kartonpapírból, a keretet kiszínezhetik, kidíszíthetik, a lencse helyére betehetnek színes fóliát. Ha elkészült a szemüveg, eljátszhatjuk, hogy mivé alakulhatnak a bennünket körülvevő tárgyak (Próbáljátok ki a szemüvegeiteket az alábbi helyszineken! Tornaterem: Mivé változik a bordásfal, a mászókötél, kosárpalánk, zsámoly? Csoportszoba: Mivé változnak az asztalok, székek, az evőeszközök, tányérok, poharak? Udvar: Mivé változnak a fák, bokrok, padok, játékok? Mosdó: Mivé változik a csap, vécékagyló, ajtó, kilincs?). A játék végén készíthetünk kollázst (rongyokból, színes újságokból), majd rendezhetünk egy kiállítást.

A drámapedagógia metodikájának alkalmazása a tanulásban-nevelésben többirányú nyitottságra, toleráns, demokratikus gondolkodásmódra ösztönöz, segíti a kölcsönös megértést, az empátiát. A mesereprodukció által fejlődik a gyermek reproduktív (újraalkotó) és produktív (alkotó) fantáziája, ehhez a megfelelö légkör, a folyamatos irodalmi élménynyújtás, a gyermeki önkéntelen felfedezés, tapasztalás, a szinkretikus sémák biztosítása szükséges a pedagógus részéről.

\section{Összegzés}

Úgy gondoljuk, hogy a drámapedagógiai módszerek és a mesereprodukciós formák tudatos és szakszerủ alkalmazása ösztönzi a gyermekeket a történetezés és narratívateremtés örömének felfedezésében, segítve szövegértésük és logikus gondolkodásuk fejlődését. A tanulmányban igyekeztünk példákat hozni az interaktív tevékenységi módok, a komplex személyiségfejlesztő drámajátékok, a projekt-pedagógia elveire épülő drámatervek óvodai alkalmazására. Véleményünk szerint az élménypedagógiai módszerekre épülő drámaterveknek az óvodai nevelésben-fejlesztésben kiemelt figyelmet kell szentelni, hiszen serkenthetik az óvodáskorú gyermekeket az irodalom iránti fogékonyságra, ösztönözhetik őket történetmondó tevékenységük alakításában, fejlődésében.

\section{Irodalom}

Adamikné Jászó, A. (2001). Gyermekirodalom és nemzeti azonosságtudat, Elektronikus Könyv és Nevelés, 3. évfolyam 2. szám. https://epa.oszk. hu/01200/01245/00010/cikk14.html

Benedek, E. (1989). Magyar mese- és mondavilág 3. Móra/Téka.

Bódis, Z. (2005). Gyermek, nyelv, költészet, Új Forrás, 37(5), o. n.https://epa.oszk. $\mathrm{hu} / 00000 / 00016 / 00105 / 050509 . \mathrm{htm}$

Boldizsár, I. (2003). Varázslás és fogyókúra. Didakt.

Buzás, Z., \& Maródi, Ágnes. (2018). A kottaolvasás és az orientációs képesség összefüggésének vizsgálata online tesztkörnyezetben. Gyermeknevelés Tudományos Folyóirat, 6(2), 49-63. https://doi.org/10.31074/gyn201824963 
Csimota Kiadó Design-sorozat könyveiről: http://csimota.hu/hu/konyvcimke/design/

Dankó, E. (2000). Nyelvi-kommunikációs nevelés az óvodában. Okker Kiadó.

Dankó, E. (2004). Irodalmi nevelés az óvodában. Okker Kiadó.

Daróczi, G. (2014). Az óvodáskorú gyermekek kognitív müveleteinek fejlesztési lehetőségeiirodalmi kommunikációval.KönyvésNevelés, 26(2), o.n.http://olvasas. opkm.hu/portal/felso_menusor/konyv_es_neveles/az_ovodaskoru_gyermekek_ kognitiv_muveletei_fejlesztesi_lehetosegei_irodalmi_kommunikacioval

Donauer, N (2016). A diszlexia mitosza - avagy az olvasás fejlesztési lehetôségei kis és nagyiskolás korban. http://pakvim.net/watch/PF6TD6OTLfU, (2016. április 8.)

Fazekasné Fenyvesi, M. (2006). Az akusztikus és vizuális észlelés szerepe az olvasástanulásban. In Józsa, K. (Ed.), Az olvasási képesség fejlődése és fejlesztése (pp. 189-206). Dinasztia Tankönyvkiadó.

Finy, P. (2011). A csodálatos szemüveg. Naphegy Kiadó.

Gósy, M. (2000). A hallástól a tanulásig. Nikol GMK.

Gönczöl, A. (2019). Educational reading in preschool with methods of drama pedagogy. Complex personality development effect of tale. In Bordás, S. (Ed.), Módszerek, müvek, teóriák. A X. Tantárgy-pedagógiai Nemzetközi Tudományos Konferencia elöadásai (pp. 123-132). Eötvös József Főiskolai Kiadó.

G. Gődény, A. (2014). Az Olvasók Birodalma. Az olvasóvá nevelés jelenkori esélyei és lehetőségei. Könyv és Nevelés, 16(1), 32-41.

Janurik, M. (2008). A zenei képességek szerepe az olvasás elsajátításában. Magyar Pedagógia, 108(4), 289-301.

Lázár, E. (2006). Bab Berci kalandjai. Osiris.

Réger, Z. (2002). Utak a nyelvhez. Nyelvi szocializáció - nyelvi hátrány. MTA Nyelvtudományi Intézet.

Révész Emese (2019). A vizuális narráció eszköztára a Design-könyvek sorozatában. Gyerekvilágok - Studia Litteraria, 1-2, 166-193.

Szinger, V. (2003). Interaktív mesemondás és meseolvasás az óvodában. Anyanyelvpedagógia, 3. sz. http://www.anyanyelv-pedagogia.hu/cikkek.php?id=184

Thompson, W. F., Schellenberg, E. G. \& Husain, G. (2004). Decoding speech prosody: Do music lessons help? Emotion, 4(1), 46-64. https://doi.org/10.1037/15283542.4.1.46

Varga-Mukri, E. (2019). A mese és a teremtö gyermeki képzelet. A gyermeki szövegalkotás lehetöségei szakdolgozat. ELTE TÓK. 


\section{Gönczöl, A.}

\section{Educational reading in preschool with methods of drama pedagogy}

\section{The complex effects of stories on the development of personality}

The focus of the study is on raising the reading skills of pre-school children and awakening their curiosity towards literature. The author's aim is to present the techniques of drama pedagogy that can be of theoretical and practical use in the promotion by kindergarten teachers of children's speech and behaviour, as well as emotional intelligence and such fundamental ethical categories and concepts as acceptance, openness, and tolerance. The professional deployment of dramatic pedagogical methods and forms of story re-telling encourages children to discover the joys of creating history and narrative, helping to improve their literacy and logical thinking. In the presentation, the introduction of interactive modes of action, complex personality development drama, and drama designs based on the principles of project pedagogy play a prominent role.

Keywords: reading comprehension, reader education, story re-telling, story making, drama pedagogy

Gönczöl Andrea: https://orcid.org/0000-0002-5438-8528 